\title{
Investigating Flexibilities of the Classroom Teachers for Four Operations in the Basis of Different Strategies*
}

\section{Sınıf Öğretmenlerinin Farklı Stratejiler Temelinde İşlemde Esnekliklerinin İncelenmesi}

\author{
Ebru AYLAR-ÇANKAYA**
}

Received: 12 November 2019

Research Article

Accepted: 17 July 2020

\begin{abstract}
Four operations algorithm is among the major topics occupying a significant position in primary school schedule. Moreover, utilizing alternative strategies during the education process and improving operation flexibility of students also considered important in teaching of mathematics. Flexibility in computing is the ability of solving any operation also by using various cognitive or model based calculation strategies with different methods. Giving place for these strategies in education process for improvement of skills of using different strategies and guiding students enabling them to develop their own strategies is important. In this study, in addition to the teaching the standard algorithm, covering a massive place in our courses, it is aimed to review the classroom teachers' opinions for the alternative strategies of four operation that means their flexibility in the procedural process (procedural flexibility). The procedural flexibility is discussed through strategies and standard algorithms using preliminary learning such as modeling, mental processing and place value concept. It is a qualitative study conducted in 2018-2019 academic year with 45 classroom teachers. In the study, a 2-question open-ended question form based on multiplication and consisting of two different scenarios was used as data collection tool. The most favorite strategy preferred by teachers according to the findings obtained from this form is standard algorithm followed by mental process strategy. However, teachers showed no flexibility in the process, they did not prefer other alternative strategies given about multiplication and they reported negative opinions about some of them.
\end{abstract}

Keywords: Flexibility, standard algorithm, mental processing, modeling, place value concept.

ÖZ: Dört işlem algoritması ilkokul programında önemli yer tutan konu başlıklarındandır. Ayrıca, öğretim sürecinde alternatif stratejilerin kullanımı ve öğrencide işlemde esnekliğin geliştirilmesi de matematik eğitiminde önemsenmektedir. Hesaplamada esneklik herhangi bir işlemi çeşitli zihinsel veya model temelli hesaplama stratejilerini de kullanarak, farklı yollarla çözebilme becerisidir. Farklı stratejileri kullanma becerisinin öğrencilerde gelişmesinde öğretim sürecinde bu stratejilere yer verilmesi, öğrencilerin kendi stratejilerini geliştirmesinde onlara rehberlik edilmesi önemlidir. Bu araştırmada şu an hizmet yürüten sınıf öğretmenlerinin, derslerimizde büyük yer kaplayan geleneksel algoritmanın öğretimine ek olarak, dört işlemin alternatif stratejilerine yönelik görüşlerini yani işlem sürecindeki esnekliklerini incelenmek amaçlanmıştır. İşlemde esneklik modelleme, zihinden işlem, basamak kavramı gibi ön öğrenmelerin kullanıldığı stratejiler ve geleneksel algoritma üzerinden ele alınmıştır. Araştırma 2018-2019 öğretim yılında, 45 sınıf öğretmeni ile birlikte yürütülen bir nitel araştırmadır. Araştırmada veri toplama aracı olarak, çarpma işlemini temel alan ve iki ayrı senaryodan oluşan, 2 soruluk açık uçlu bir soru formu kullanılmıştır. Bu formdan elde edilen bulgulara göre öğretmenlerin en çok tercih ettikleri strateji geleneksel algoritma, hemen ardından da zihinden işlem stratejisi olmuştur. Buna karşın öğretmenler işlemde esneklik göstermemiş, çarpma işlemi ile ilgili verilen alternatif stratejileri hem tercih etmemiş, hem de bazıları hakkında olumsuz görüş bildirmişlerdir.

Anahtar kelimeler: Esneklik, geleneksel algoritma, zihinden işlem, modelleme, basamak değeri kavramı.

\footnotetext{
* A part of this article was presented as an oral presentation at the VI th International Eurasian Educational Research Congress (EJER 2019).

** Corresponding Author: Asst. Prof. Dr., Ankara University, Ankara, Türkiye, eaylar@ankara.edu.tr, https://orcid.org/0000-0003-0455-3553
}

Citation Information

Aylar-Çankaya, E. (2020). Investigating flexibilities of the classroom teachers for four operations in the basis of different strategies. Kuramsal Eğitimbilim Dergisi [Journal of Theoretical Educational Science], 13(4), 646-662. 
Although recently, four arithmetic operations algorithms have been implemented in our schools through a single method, nowadays the view that importance of learning and using multiple / diverse strategies gain weight. For instance, when multiplying 140 to 5, may think to carry on algorithm procedure by writing these numbers one under the other with the discourse of "5 times 1 equals 5". None the less the same procedure can be realized faster by multiplying half of 140 to 10 . Or each piece, by taking 140 in two parts like 100 and 40, can be separately and mentally multiplied with 5. It is then possible to address the result of any procedure with a variety of strategies rather than a single strategy. Some studies and reports exhibit the fact that especially the existence and development of strategy diversity based on reasoning improves four operation algorithm learning (Baroody, 2003; Henry \& Brown, 2008; National Council of Teachers of Mathematics [NCTM], 2000). Despite the fact that after giving the definition of any four operation, teaching directly the standard algorithm rule of this operation negatively affecting mathematical development (Baroody, 2006), it is a widely used approach.

Against this approach, two more different algorithm teaching approaches developed within the historical process (Van de Walle, Karp and Bay-Williams, 2013). In the first approach (explicit strategy instruction), students' opinions are supported and strategies are taught through meaning rather than memorized implementation. The last approach is considered as "guided invention" (Gravemeijer \& van Galen, 2003). Students are more active in this approach and it is aimed to improve and utilize most appropriate strategies for their own learning by presenting them minor guidance. For instance, in $8+9$ computation while a student develops a strategy adding one to two times eight, the other may prefer to subtract 3 from 20 because of one and two proximity of numbers 8 and 9 to 10 . Another student, by taking one from 8 and adds it to 9 and may apply a strategy to realize the procedure as $7+10$. This last strategy involves the existence of many strategies and a combination of these strategies in the teaching process. Teacher guides student in this process and assists development of the strategy diversity.

When NCTM (2000) mentions on gaining fluency in computational strategies and learning by understanding four operations during primary school, they emphasize the necessity of selecting effective / correct method by the students. While Van de Walle, et al. (2013) mention on the necessity of expanding our point of view towards calculation, focuses on three calculation types used in different methods of the four operation algorithm. Among those, a consecutive advancing development process is also defined. The first is direct modeling. At this stage, the student builds the process he/she deals with through direct manipulatives and basically attains the result with counting strategies. In development step following the modeling, student reaches to the result of the calculation by mostly using mental methods and by dividing the numbers. This approach is called student invented strategies. Last calculation type is a standard algorithm, numbers are written one under the other in this approach and place value of the number is taken into account thereby the process realized in steps.

All these strategies demonstrate that any four operations procedures can be handled flexibly. Flexibility in the procedural process (procedural flexibility) can be handled as a diversity of strategies used to solve a same kind of work (Whitacre \& Rumsey, 2018). Flexibility in computing can be considered as a skill and tend to use 
various mental calculation strategies, and being not flexible can be considered as being dependent on standard algorithms (Markovits \& Sowder, 1994).

Capacity of having knowledge not only for a single algorithm but different strategies and to be able to use them jointly, namely procedural flexibility, cannot automatically developed by the students during school period. Whether teachers use different strategies in their lessons or not, and the content of applied programs set students' trend to develop different strategies or using these strategies (Fuson et al., 1997). When students encounter a problem status, for example when adding two digit numbers, they tend to apply the strategy that they learn for the first time and that they mostly encounter and apply. In this point, teachers should seek and utilize appropriate methods to make their student see there are also different solution strategies and to direct them towards these strategies. One of these methods can be making a discussion in the classroom what kind of strategies can be used and which other kind of strategies can also be used (Erdoğan \& Erdoğan, 2015). The development and implementation of such approaches depends primarily on the teachers' approach to this task. For that reason whether teachers give place to different solution strategies when teaching four operations and their opinions for the functionality of these strategies affect their teaching process.

However studies in the literature demonstrated that teachers and preservice teachers both in Turkey and in abroad rather focused on memorizing not learning by understanding in their lessons, their lecture remained in rule transfer level, they usually utilize standard solution methods in a non-flexible way for the solution of problems and they do not have fluency and flexibility in the procedural process (Bachman \& Walters, 2018; Baki, 2013; Hacıömeroğlu, 2013; İşleyen \& Işık, 2003; Kılcan, 2006; Korkmaz \& Gür, 2006; Thanheiser et al., 2014; Toluk - Uçar, 2011; Yenilmez \& Uygan, 2015). None the less, number of studies made with classroom teachers unfortunately very limited in our country. There is no study dealing with approaches and competences of the classroom teachers in relation with the alternative strategies of the four operation processes executed in Turkey. This research contributes to the literature in this regard.

In this study, in addition to teaching the standard algorithms occupying a big space in our classes, it is also aimed to investigate classroom teachers opinions intended for alternative strategies of the four operations. In these alternative strategies, strategies utilizing pre-learning such as modeling, mental processing and place value concept will be discussed.

\section{Method}

The study is a descriptive qualitative research aiming to present the classroom teachers' approaches to alternative solution strategies used in the process through multiplication example.

\section{Study Group}

Forty five classroom teachers attended to this study from five separate public schools from two different districts in Ankara. The schools are those in which students from upper-middle and lower-middle socio-economic levels are educated. The study has been realized with the teachers who took part in an in-service training executed in coordination with Ankara Directorate of National Education (AMEM). The data were 
collected by the researcher before in-service training. The teachers' participation was voluntary. An easily accessible sampling method was used in the study group of the study. The teachers' distribution by their years of service is given in Table 1 .

Table 1

Distribution of the Teachers Attending to the Study According To Their Service Years

\begin{tabular}{lcccc}
\hline Service Years & $1-10$ & $11-20$ & $21-30$ & 31 and over \\
\hline $\begin{array}{l}\text { Number of Teachers } \\
(\mathrm{n}=45)\end{array}$ & 4 & 13 & 26 & 2 \\
Percentage $(\%)$ & 9 & 29 & 58 & 4 \\
\hline
\end{tabular}

While twenty five of these teachers are graduated from faculty of education or teacher schools, twenty teachers are graduated from different departments such as chemistry department or agriculture engineering department of engineering faculty. There are thirty five female and ten male teachers in the study. The majority of the study group consists of experienced teachers. This situation is harmony with the general profiles of classroom teachers working in central districts in Ankara.

\section{Data Collection Process and Data Analysis}

Data were collected in the spring semester of the 2018-2019 academic year. An open-ended questionnaire consisting of two scenarios based on multiplication was used as data collection tool. The test developed in the "Integrating Mathematics and Pedagogy, [IMAP]" project by Ambrose, Philipp, Chauvot and Clement (2003) was used for the creation of the questionnaire. The first question in the questionnaire which was inspired by this test was also used in an other study by the Ören Vural, Aylar Çankaya (2020). The other question was presented to the expert opinion of an academician who has expertise in the field of mathematics education and the question was finalized according to his/her views. Since the ethics committee decision was not requested from the manuscripts in 2019, ethics committee decision was not taken in this study. However, ethical rules were followed at all stages of the research.

In the first question teachers were presented a scenario including four different answers of the students for " $15 \times 19$ " process was presented to the teachers (see Figure 1). 
Figure 1. First Question in the Questionnaire

1. Aşağıda 4. sınıfa giden 4 öğrencinin " $15 \times 19$ " işlemi için vermiş olduğu yanıtlar bulunmaktadır.

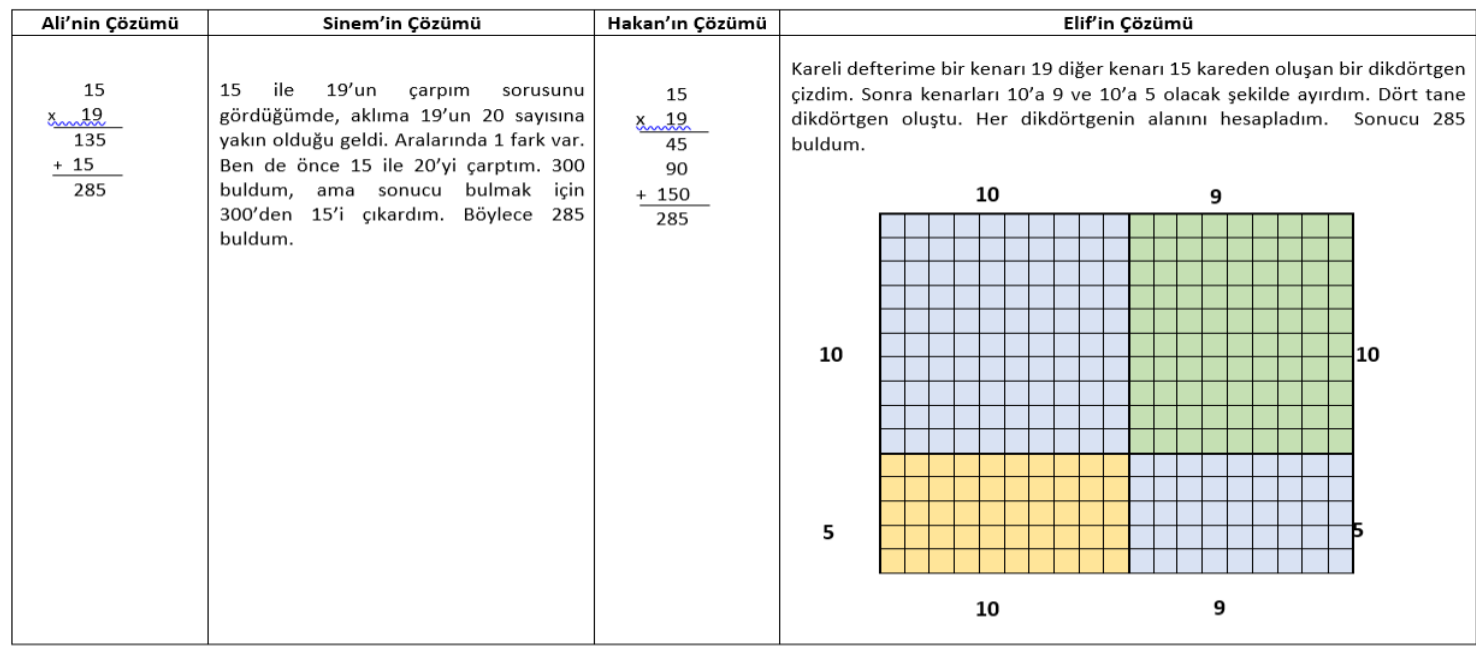

1. Below are the answers given by the four 4th grade students for multiplication "15x19". Sinem's solution: "When I saw the multiplication question of 15 and 19 , I was reminded that 19 was close to the number 20 . There's 1 difference between them. I multiplied 15 and 20 first. I found 300, but I subtracted 15 out of 300 to get the result. So I found 285.". Elif's solution: "I drew a rectangle of 19 squares on one side and 15 squares on one side. Then I splitted the edges into 10 to 9 and 10 to 5. Four rectangles were formed. I calculated the area of each rectangle. I found 285."

One of these answers presents solution with standard algorithm, the other is a strategy where mental calculation with easy applied multiplications are used, the other is a strategy appeared to be standard however a calculation executed as dominant with the place value concept and the last one presents an approach built over modeling. The teachers were first asked to examine the answers of the students and then to answer open-ended written questions about these answers. The open ended questions were about teachers' opinion weather they find students' answers meaningful and which of these answer / answers they prefer their students to use.

In the second question, a multiplication process performed by the teachers in a standard algorithm and the question presented by a student in the class through this process are given as a scenario (see Figure 2). The teachers were asked how they would respond to this question of students.

Figure 2. Second question in the questionnaire

2. Ahu çarpma işlemini öğrenirken öğretmenin yan tarafta yer alan tahtaya yazdığı işlemi görünce parmak kaldııı ve sorar : "Öğretmenim 2 ile
2'yi çarparken niçin bir basamak boşluk bırakarak yazıyoruz?" Siz öğretmenin yerinde olsanız Ahu'ya ne yanıt verirsiniz?
$\begin{aligned} & 248 \\ & 288\end{aligned}$

2. When learning multiplication Ahu raises her hand and asks following question when she see the calculation written by the teacher on the board: "Sir/mam why you leave a one-digit gap when multiplying 2 by 2 ? "How would you respond to Ahu if you were her teacher? 
The data collection process was carried out in a classroom where the teachers wrote their answers individually in the questionnaire throughout approximately 40 minutes.

The data were investigated in a single question basis and assessed with content analysis. Codes on the teachers' responses were first attained for content analysis and then findings were started to be interpreted by creating themes over these codes. In addition, approximately $20 \%$ of the data (10 questionnaires) were also coded by an academician informed about the study and coding consistency was $92 \%$ according to Miles and Huberman's (1994) formula. Direct citations by using photograph were made from the teachers' scripts when reporting the findings. These citations were shared with new namings in line with their gender by keeping teachers' names confidential.

\section{Findings}

Findings were transferred by individually analyzing in question basis.

\section{Solution Strategies for Multiplication Process}

In the first question, the teachers presented four different solution strategies for multiplication process. In these strategies, Ali's response presented solution with standard algorithm, Sinem's response, a strategy with mental calculation and use of easy multiplications, Hakan's response, strategy appears to be standard but overlooking place value concept, Elif's solution presented a strategy built over an area model. Following these strategies the teachers were first asked the question "Which student / students' response did you feel more meaningful / correct?" and then "When you think about your own students, which solution method (s) do you want them to use, which one do you not want?" together with their justifications.

The teachers expressed the strategies that they found meaningful and wanted their students to use in. For instance some stated that they have found only Sinem's method meaningful and some said Sinem and Elif and some approved all the methods. The strategies they refer to and frequency of expressing these strategies are given in Table 2.

Table 2

Strategies Found to be Meaningful By Teachers

\begin{tabular}{|c|c|c|c|c|c|c|c|}
\hline Strategies & Sinem & Ali & $\begin{array}{l}\text { Ali, } \\
\text { Sinem }\end{array}$ & $\begin{array}{l}\text { Sinem, } \\
\text { Elif }\end{array}$ & $\begin{array}{l}\text { Ali, } \\
\text { Hakan }\end{array}$ & $\begin{array}{l}\text { Ali, } \\
\text { Sinem, } \\
\text { Hakan }\end{array}$ & All \\
\hline $\begin{array}{l}\text { Number of } \\
\text { the } \\
\text { teachers } \\
(n=45)\end{array}$ & 9 & 9 & 11 & 3 & 1 & 1 & 11 \\
\hline
\end{tabular}

Despite the teacher mentioned about the strategies in different sorting, the strategy that they found most meaningful and included in most of their preferences was Sinem's strategy $(n=35)$. Thereafter, they have stated that they have found Ali $(n=33)$, Elif $(n=14)$ and Hakan's $(n=13)$ strategy to be meaningful, respectively. Number of the 
teachers finding Elif and Hakan's answers to be meaningful is low. There were only eleven teachers specifying that they have found all responses meaningful.

In addition to finding meaningful or not, the teachers were asked which strategy and strategies they want their students to use. The teachers by giving similar responses to this question with the previous question, mentioned strategies in different groupings. Strategies mentioned by the teachers are given under Table 3.

Table 3

Strategies that the Teachers Want Their Students to Use

\begin{tabular}{lllllllll}
\hline Strategies & Sinem & Ali & $\begin{array}{l}\text { Ali, } \\
\text { Sinem }\end{array}$ & $\begin{array}{l}\text { Ali, } \\
\text { Hakan }\end{array}$ & Ali, Elif & $\begin{array}{l}\text { Ali, } \\
\text { Sinem, } \\
\text { Hakan }\end{array}$ & $\begin{array}{l}\text { Ali, } \\
\text { Sinem, } \\
\text { Elif }\end{array}$ & All \\
\hline $\begin{array}{l}\text { Number } \\
\text { of the } \\
\text { teachers } \\
(n=45)\end{array}$ & 5 & 7 & 11 & 2 & 1 & 5 & 2 & 12 \\
\hline
\end{tabular}

The teachers' approach towards the strategies they want their students use is parallel with their opinion for these strategies. While forty teachers stated that they prefer Ali's method, thirty five teachers preferred Sinem's method, ten teachers preferred Hakan's method and fifteen preferred Elif's methods. Only twelve teachers stated that they wanted their students to use all strategies. Teacher Zehra as one of these teachers explained her justification as follows:

Figure 3. Zehra's response

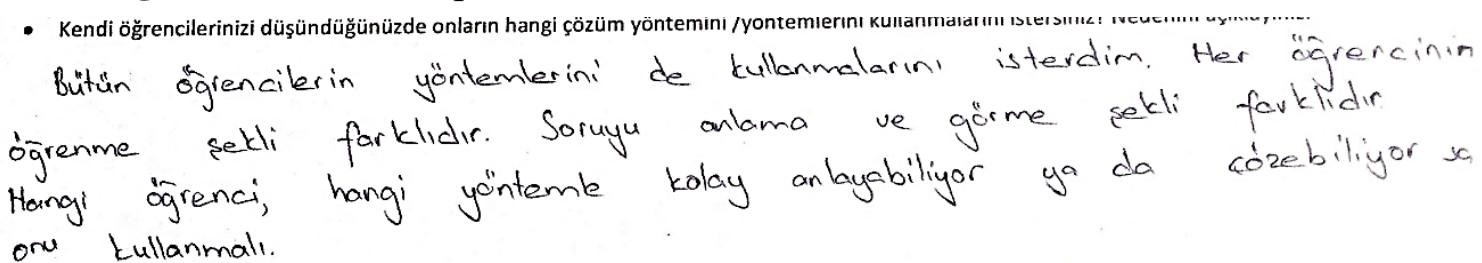

I'd prefer them to use all students' methods. Each student has different forms of learning. Their method of understanding and observing the question is different. Each student should prefer his/her method where he/she understands or solves easily.

In responses given, the preference level of Hakan and Elif's strategies was found to be low. Although some teachers found Elif's strategy meaningful, they did not prefer this method due to long modeling time. Some teachers reported that they know the necessity to include other methods other than Ali's at their lessons, however since they think that student would make less mistakes by using standard algorithm they have preferred this method. The teachers' levels of finding strategies meaningful and level of preferring to use are close to each other despite minor changes. Teachers preferred to use strategies that they found meaningful, shown no procedural flexibility by not giving place to strategy diversity in their choices. Only 19 of the teachers (42\%) made minimum three strategy choices (Ali-Sinem-Hakan, Ali-Sinem-Elif and all preferences). 
When teachers' comments on four strategies given in the question reviewed separately, it was observed that negative views on Sinem's and Ali's strategies were either absent or in a limited level. The codes most frequently repeated by teachers regarding these four strategies are given in Table 4 with the distinction of positive and negative codes.

Table 4

Code Specified on Alternative Strategies

\begin{tabular}{|c|c|c|}
\hline Strategies & Positive Codes & Negative Codes \\
\hline \multirow{4}{*}{ Sinem } & Practical & \multirow{12}{*}{ Standard } \\
\hline & Different & \\
\hline & Mental & \\
\hline & Logical & \\
\hline \multirow{8}{*}{ Ali } & Fast & \\
\hline & Easy & \\
\hline & Clear & \\
\hline & Short & \\
\hline & Classic & \\
\hline & Compatible with the curriculum & \\
\hline & Method thought & \\
\hline & Prevalent & \\
\hline \multirow{7}{*}{ Elif } & Permanent & \\
\hline & Visual & Long \\
\hline & Meaningful & Post-primary school \\
\hline & Concrete & Not practical / not functional \\
\hline & Synthesis (over the concept of & Suitable with its own idea \\
\hline & area) & \multirow[t]{2}{*}{ Mixed } \\
\hline & Top level & \\
\hline \multirow{4}{*}{ Hakan } & \multirow{4}{*}{$\begin{array}{l}\text { Place value concept } \\
\text { Described Ali's way } \\
\text { Interesting }\end{array}$} & Post-primary school \\
\hline & & Not practical \\
\hline & & Suitable with its own idea \\
\hline & & Mixed \\
\hline
\end{tabular}

The teachers' views on standard algorithm (Ali's method). One of the methods most preferred by teachers in both sub-questions was the standard algorithm. As it can be seen from codes given in Table 4, some of the teachers emphasized the standard aspect of this method, explained that they were compatible with the curriculum and explained their preferences by citing that this was the most widely used strategy. Some teachers preferring this method stated that standard algorithm was shorter, easy and clear. While most of the teachers considered the standard aspect of this method as a positive parameter, some teacher even few stated that they have found this method to be very standard (negative code) and emphasized that it was closed to new and alternative approaches and so they made negative assessments. 
The teachers' views on mental strategy (Sinem's method). One of the methods most preferred by teachers was Sinem's method reflecting a process from the mind. None of the teachers reported negative views for this strategy. Although some teachers stated that they found this method different and did not use it in their classrooms, they found that the content of the method to be reasonable. Some teachers specified that mental process was a significant skill and some found the method to be practical.

The teachers' views on place value concept (Hakan's method). One of the methods that teachers found different and interesting was this method. The teachers compared this method to standard algorithm. They've interpreted this as clarified form of Ali's method. Out of all these positive considerations, a vast amount of teachers reported negative views on this method. Some of the teachers reporting negative views failed to fully comprehend Hakan's logic that's why they have found the answer as confusing. Some of these teachers specified that Hakan created a solution in his own and the answer "was appropriate according to his view". This strategy with a correct result somehow failed to be included within these teachers' preferences. Teacher Serdar with an experience of 7 years has reported his view on this strategy as "Hakan complicated an easy procedure with his own solution". View claiming that this strategy is a bit hard for primary school also repeated by some of the teachers, these teachers also reported that this strategy could be used in post - primary school phases. Views on the fact that the strategy was hard, were generally consolidated in views intended to Elif's strategy. Teacher Ezgi with an experience of 19 years mentioned her approach to these strategies as follows.

Figure 4. Ezgi's respose

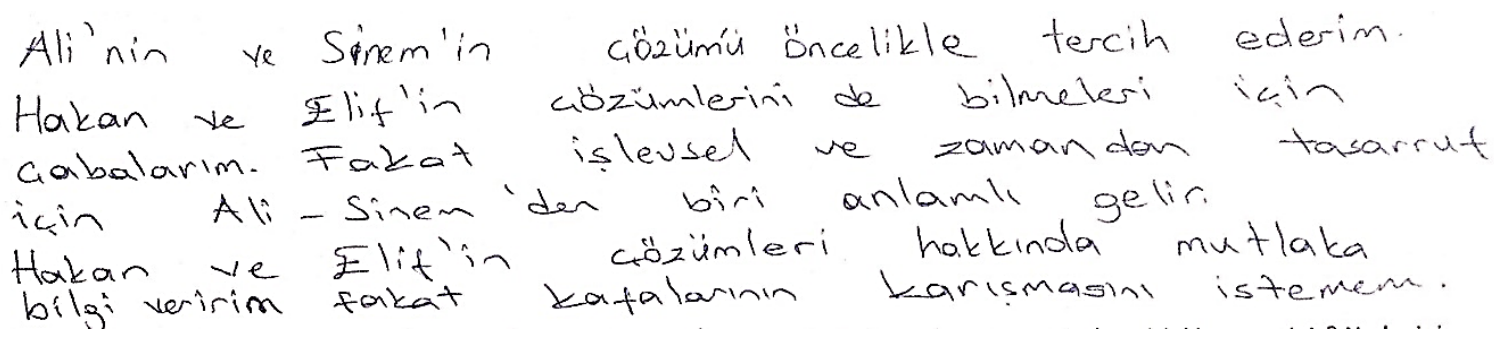

I would rather prefer Ali's and Sinem's solution. And I can spend efforts to let them know Hakan and Elif's solutions. However in terms of functions and time saving, one of the methods of Ali and Sinem's would be meaningful. I will absolutely inform about Hakan and Elif's solutions however I do not want to make their minds confused.

The teachers' views on strategy where modeling is used (Elif's method). The method that teachers least wanted their students to use was the method involving modeling. Teachers with affirmative views about this strategy mentioned that Elif knew the meaning of multiplication and she visualized this meaning with modeling and made it comprehensible. Unfortunately, numbers of these teachers were limited $(n=12) .3$ teachers with positive approach to this strategy, although they found strategy's level was over the primary school level, mentioned that this method thought was a smart approach since they have considered area and multiplication as a separate subject. These teachers failed to move beyond the meaning of multiplication process compromising repetitive adding and failed to consider area relevant model as the 
conceptual content of the procedure. While a teacher with 15 years of experience making an assessment as "Elif has built up relation among subject and consolidated the area subject with multiplication process" by the way, a teacher with 6 years of experience claimed that "she made a synthesis by consolidating different subjects, a top level of process was realized".

Similar to the examples above, some of the teachers who purported negative opinions on modeling found Elif's method above the primary school level and they have stated that they shall not prefer this method in primary school level for that reason. Even, a teacher with 24 years of experience, by making an assessment that "Elif's solution was interesting, and had intelligence" and mentioned this strategy's level as far more advance classes. Other teachers, who reported negative opinions, evaluated this method as a long, mixed and complicated strategy and therefore having a high probability of making mistakes. The response of one of these teachers is given in Figure 5. Expressions of some teachers as "I never used Hakan and Elif's method, I need to think about them", "I took time to study Elif's method and Elif did it right", "It took me a while to figure out what Elif was doing, my students would never understand", etc., demonstrated that the teachers are not familiar with modelling intended for multiplication procedure and they could not attach meaning to the modelling processes.

Figure 5. Kaan's response

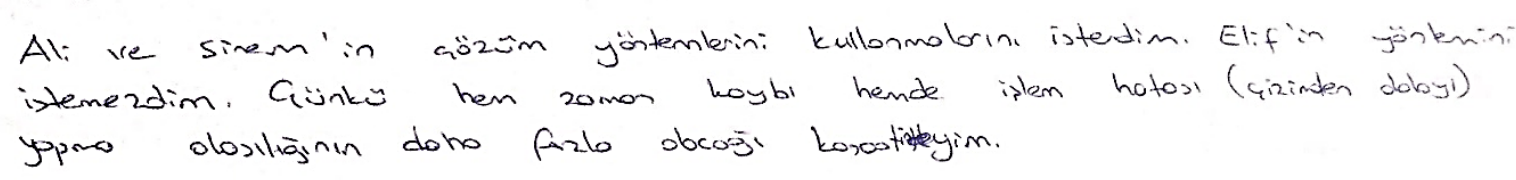

I would prefer that they use Ali's and Sinem's solution method. I don't prefer Elif's method. Because, it is both waste of time and also rises the probability of making calculation errors.

\section{Conceptual Knowledge Dimension}

The second question mainly reveals the conceptual knowledge dimension of teachers' understanding of standard algorithm teaching. In this question, teachers are expected to answer the student's question in the given scenario. The answers to this question were primarily encoded depending on the concepts that the teachers expressed most intensively. Thereafter these codes were grouped under the following themes; empty, no justification, rule transfer, conceptual content. The no justification theme consists of descriptions not containing effort of presenting justification. In the rule transfer theme there are definitions where algorithm information is only transferred in procedural level and definitions where conceptual basis is not discussed. The conceptual content theme contains explanations where information about the multiplication algorithm is presented at the conceptual and procedural level. Numeric distribution of teachers under these themes is given in Table 5 . 
Table 5

Themes for the Second Question and Numeric Distribution of Teachers in These Themes

\begin{tabular}{lllll}
\hline Themes & Empty & No justification & Rule transfer & $\begin{array}{l}\text { Conceptual } \\
\text { content }\end{array}$ \\
\hline $\begin{array}{l}\text { Number of Teachers } \\
(n=45)\end{array}$ & 3 & 4 & 31 & 7 \\
\hline
\end{tabular}

As it can be seen from Table 5, the teachers' (31 teachers) responses to students were mostly related with the transfer of standard algorithm rule of the multiplication process. Responses of these teachers were gathered under codes "digits", and "digit dragging". The answers under this theme were explanations where superficial information was presented, even if the digit concept was mentioned not addressing the conceptual basis of the process of the algorithm. For instance, teacher Aysel with 20 years of experience explained her original stair rule developed by using "digit dragging" discourse as follows:

Figure 6. Aysel's response (Rule transfer theme)

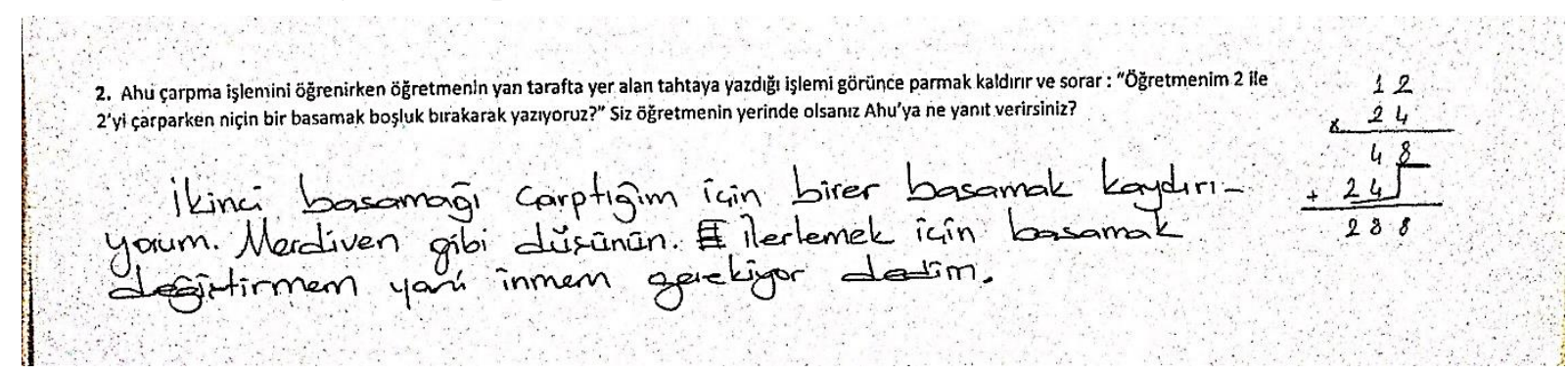

Since I multiply the second digit, I drag one digit each. Think of it as a stair. I said I need to shift digits to go down to advance.

Another teacher's response under this theme is given in Figure 7. In this answer, the teacher focused only on the numbers, she didn't mentioned on the reason of the digit dragging.

Figure 7. Zeynep's response (Rule transfer theme)

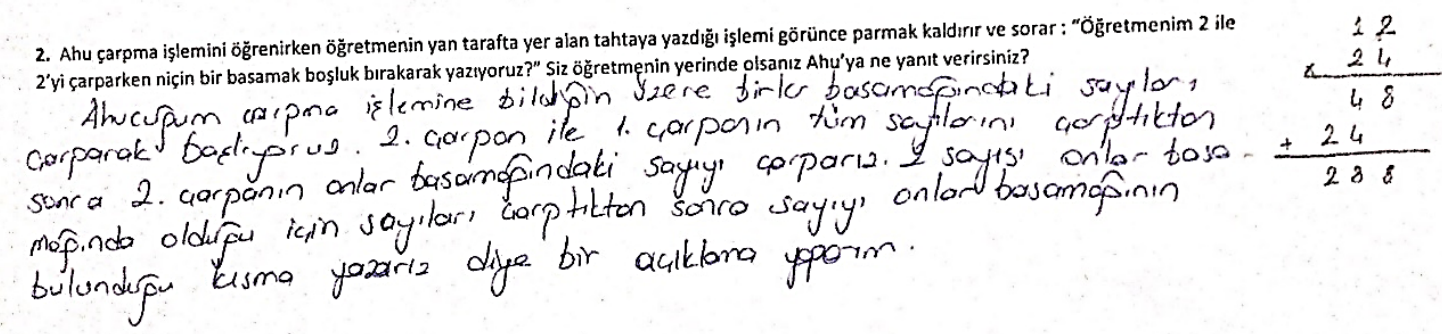

I would make a statement that "Ahu, as you know we start with the multiplication process by multiplying the numbers in units' digit. We multiply the number in tens digit of the 2nd multiplier after we multiply all numbers of 2nd multiplier and 1st multiplier. Since the number 2 is in tens digit we write the number on the part where tens digit exist after multiplying the numbers." 
Teachers' statements with similar contents like "Since 2 is in the tens digit in the 24, we also start to write the result of the multiplication from the tens digit.", "Whichever digit we multiply by is written under that digit" exits under the same theme. In all these statements, an explanation was tried to be presented, but the explanation was limited with the exact transfer of the rule. All these clarifications are in procedural knowledge level.

Four teachers have come up with short responses like "if we shall not drag the result will be wrong, this is the rule", "I will explain how a multiplication should be made by one by one with rules", they gave no information on multiplication algorithm. For that reason, since these answers fail to present a justification to the student are gathered under theme "no justification". Answers of four teachers herein are encoded with codes such as "this is the rule" or "that's the truth".

Only 7 of the forty five teachers, by mentioning digit dragging justification during multiplication specified that 2 times 2 is the multiplication of 20 times 2 in standard algorithm and they were able to give response with a conceptual content to the student's question. Answers under this theme are encoded with "place value" code. Teacher Mehmet's response under "place value" code is presented under Figure 8 and teacher Arzu's response where she has transferred standard algorithm of multiplication process grounding on place value of the numbers in the multiplication process is presented under Figure 9.

Figure 8. Mehmet's response (Conceptual content theme)

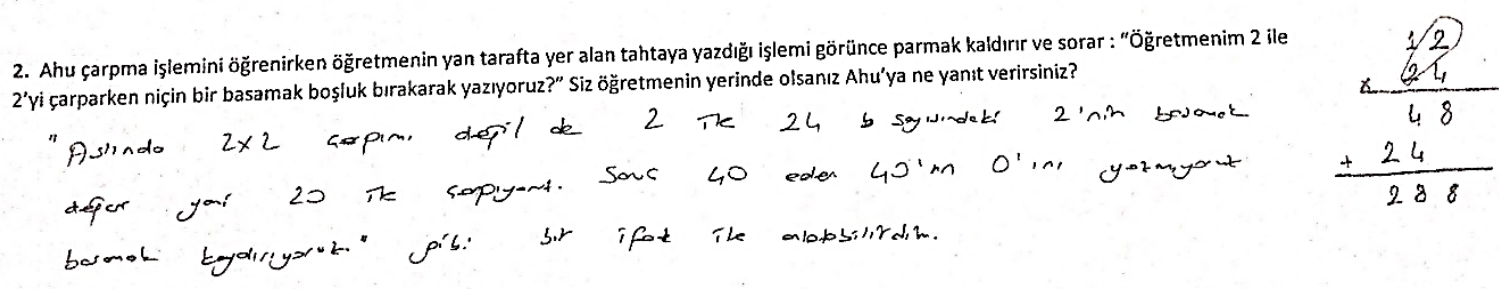

We could express with a statement that "In fact I multiply with the place value of 2 in 24 that is 20 instead of $2 \times 2$. Result is 40 , we do not write " 0 " in 40 , we drag digits."

Figure 9. Arzu's response (Conceptual content theme)

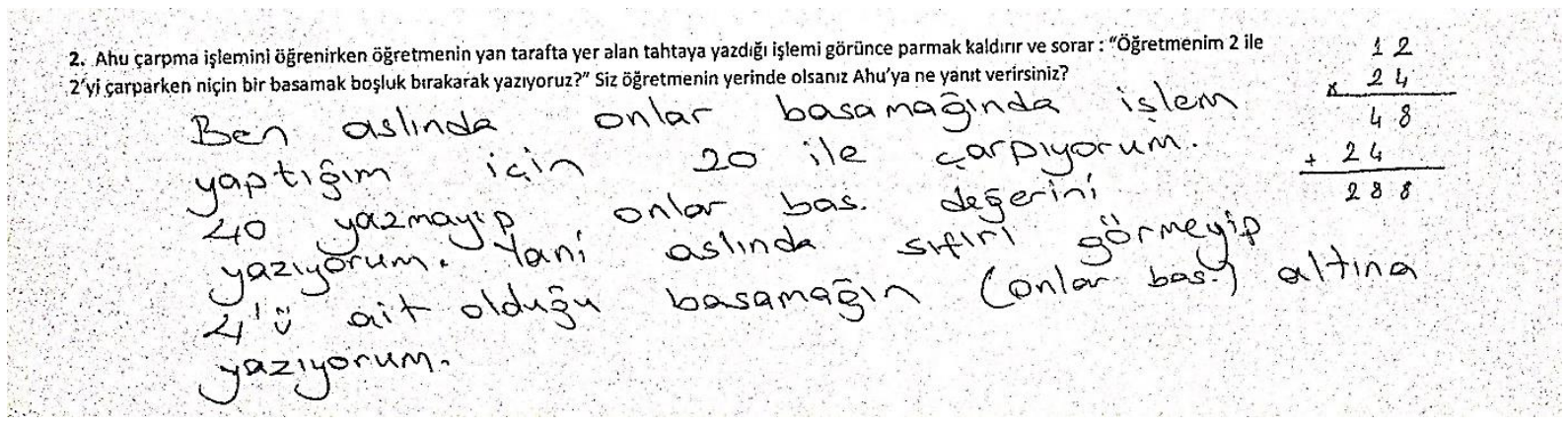

In fact, I multiply with 20 since I proceed in tens digit. I do not write 40 but write the place value of tens digit. That is, I do not see 0 but write 4 under its relevant digit (tens digit). 
The teachers mostly approached the question by using the standard algorithm of multiplication on the axis of procedure / rule teaching and made statements not mentioning conceptual basis of the algorithm. Only 7 teachers made a consideration that assesses both conceptual and procedural knowledge together.

\section{Discussion and Recommendations}

In the study, the classroom teachers with different years of service were asked to develop educational explanation for the standard algorithm over the example of multiplication. Similar with other studies made with preservice teachers (Baki, 2013; Kinaach, 2002; Millsaps, Underwood-Gregg, 2018; Toluk Uçar, 2011) descriptions developed by vast amount of teachers in this study remained in procedural knowledge level (rule transfer). Only seven teachers (approximately 16\% of teachers) were able to develop explanations referring to the conceptual basis of the process.

The findings obtained from the first question of the questionnaire used for the study demonstrated that the classroom teachers preferred solution primarily realized with standard algorithm and thereafter they have preferred mental process. In Haciömeroğlu's (2013) study realized with preservice classroom teachers and executed over subtraction computation, a vast amount of preservice teachers preferred standard algorithm to other strategies. In another study that Ören Vural and Aylar Çankaya (2020) conducted with preservice classroom teachers by using the same question, in contrary with these findings, standard algorithm was the last preference strategy of the preservice teachers. In that study, the preservice teachers were skeptical about the process and the result achieved with the traditional algorithm, and they have mentioned that achieving the correct result did not show to hold conceptual knowledge of that computation. While the standard algorithm was related with "memorizing" and being "result focused" for them, for teachers in this study the standard algorithm was a(n) "classical", "easy" and "clear" strategy. In the Ören Vural and Aylar Çankaya's (2020) study, while the preservice teachers discussed learning by making a distinction between conceptual and procedural knowledge, in this study the classroom teachers have approached to learning and knowledge with more standard norms.

The standard algorithm is an algorithm that makes the process easier and faster to run, especially in multi-digit numbers. It is important not to see algorithm teaching as a transfer of procedural knowledge, and algorithm teaching be considered together with modeling and conceptual dimension. However, with thanks to this approach it shall be prevented to consider standard algorithm as memorized information and being applied accordingly. In this study, the classroom teacher's teaching method of the standard algorithm was not considered, however only their clarifications on algorithm were examined. In future studies, it will be useful to examine how the current teachers are teaching the standard algorithm in terms of gaining more detailed analysis of the current situation.

In this study, the classroom teachers did not find it necessary to use different strategies in a wide spectrum, in this respect they failed to demonstrate procedural flexibility. This finding also differentiated the finding of Ören Vural and Aylar Çankaya's (2020) study where the same question was used. In the study conducted with preservice teachers, while almost half of the participants stated that they found it important to use all the strategies, this rate was only $27 \%$ in this study. In this study, in 
parallel with the studies of Korkmaz and Gür (2006) and Haciömeroğlu (2013), the teachers significantly preferred the standard methods. In addition to this method, the teachers preferred the strategy reflecting the mental method. The mental method and standard algorithms were two strategies that classroom teachers care about.

The findings demonstrated that the teachers abstained from alternative - flexible strategies and modelling, which were out of the standard algorithm and the mental method. The teachers were not familiar with other two strategies (modeling and place value method), they reported that they didn't use them in their lessons and also some of the teachers had difficulty to understand the strategies in the first phase. The teachers interpreted these strategies as strategies in parallel with "their own ideas". Same finding was detected in Haciömeroğlu's (2013) study. In her study, a procedure similar to the procedure performed by Hakan based on the place value concept was used and some preservice teachers failed to completely understand this procedure and they used his / her "own method" identification. In spite of that in Haciömeroğlu's study, in contrary with this study modeling was the second most preferred method.

There had been many studies on teachers' and preservice teachers' skills and their attitudes towards modelling. In Haciömeroğlu (2013) and Ören Vural and Aylar Çankaya's (2020) studies while preferences of preservice teachers on strategy involving models were higher, in this study, teachers' negative opinions about modeling and model usage were higher. The origin of these negative opinions may be the difficulties that teachers have in understanding the model and modeling. At Saleh, Purwanto, Sudirman and Hidayanto's (2018) study conducted with preservice teachers, they were able to model the $23 \times 45$ on the area model, but they could not attribute meaning to the computation carried out on the model. The modeling is not only a topic forcing students, is also a topic forcing teachers and preservice teachers. Problems encountered by the teachers and preservice teachers during the modeling process are also revealed in some studies in our country. (Akgün, Ciltaş, Deniz, Çiftçi, Işık, 2013; Işık, Mercan, 2015; Özdemir, 2008; Tuna, Biber, Yurt, 2013). In this study, modeling skills of the teachers were not investigated, only the teachers' problems related to modeling were discussed through their views. The negative views of the teachers about modeling could be considered under the headings that "modeling took time", "the possibility of making mistakes" due to this and "not being suitable for primary school level". These findings of the study is consistent with the findings obtained from Akgün et al. (2013), Blum (1991), Işık and Mercan (2015) and Urhan and Dost's (2016) studies. However, modeling skills of the classroom teachers are another important topic that should be investigated. In addition to the findings of this study, modelling skills of the classroom teachers intended for four operation should be considered as a subject matter of a new study. It is important that the preservice teachers and teachers develop their knowledge and skills for modeling and pre-service and in-service regulations should be made for this. Headings like modeling, procedural flexibility, co-development of procedural and conceptual knowledge of four operations should be improved with in-service trainings to be organized for teachers. 


\section{References}

Akgün, L., Çiltaş, A., Deniz, D., Çiftçi, Z., \& Işık, A. (2013). İlköğretim matematik öğretmenlerinin matematiksel modelleme ile ilgili farkındalıkları. Adıyaman Üniversitesi Sosyal Bilimler Enstitüsü Dergisi, 12, 1-34. Retrieved from https://dergipark.org.tr/tr/download/article-file/15138

Ambrose, R., Clement, L., Philipp, R., \& Chauvot, J. (2004). Assessing prospective elementary school teachers' beliefs about mathematics and mathematics learning: Rationale and development of a constructed-response-format beliefs survey. School Science and Mathematics, 104(2), 56-69. Retrieved from https://onlinelibrary.wiley.com/doi/full/10.1111/j.1949-8594.2004.tb17983.x

Bachman, R., \& Walters, C. D. (2018). Building fluency in an arithmetic course for preservice elementary teachers. In Venenciano, L. and Redmond-Sanogo, A. (Eds.). Proceedings of the 45thAnnual Meeting of the Research Council on Mathematics Learning (pp. 89-96). Baton Rouge, LA.

Baki, M. (2013). Sınıf öğretmeni adaylarının bölme işlemi ile ilgili matematiksel bilgileri ve öğretimsel açıklamaları. Eğitim ve Bilim, 38(167), 300-311.

Baroody, A. J. (2003). The development of adaptive expertise and flexibility: The integration of conceptual and procedural knowledge. In A. J. Baroody \& A. Dowker (Eds.), The development of arithmetic concepts and skills: Constructing adaptive expertise (pp. 1-34). Mahwah, NJ: Erlbaum.

Baroody, A. J. (2006). Why children have difficulties mastering the basic number combinations and how to help them. Teaching Children Mathematics, 13(1), 22-31.

Blum, W. (1991). Applications and modelling in mathematics teaching - a review of arguments and instructional aspects. In M. Niss, W. Blum, \& I. Huntley (Eds.), Teaching of Mathematical Modelling And Applications (pp. 10-29). New York: Ellis Horwood.

Eraslan, A. (2011). İlköğretim matematik öğretmen adaylarının model oluşturma etkinlikleri ve bunların matematik öğrenimine etkisi hakkındaki görüşleri. Illkögretim Online, 10(1), 364-377.

Erdoğan, A., \& Erdoğan, E. (2015). Toplama ve çıkarma kavramlarının öğretimi ve öğrenci güçlükleri. In E. Bingölbali, \& M. F. Özmantar (Eds.), İlköğretimde Karşılaşılan Matematiksel Zorluklar ve Çözüm Önerileri (pp. 31-49), Ankara: Pegem Akademi.

Fuson, K. C., Wearne, D., Hiebert, J. C., Murray, H. G., Human, P. G., Olivier, A. I., Carpenter, T. P. \& Fennema, E. (1997). Children's conceptual structures for multidigit numbers and methods of multidigit addition and subtraction. Journal for Research in Mathematics Education, 28 (2), 130-162.

Gravemeijer, K., \& van Galen, F. (2003). Facts and algorithms as products of students' own mathematical activity. In J. Kilpatrick, W. G. Martin, \& D. Schifter (Eds.), A research companion to Principles and Standards for School Mathematics (pp. 114122). Reston, VA: NCTM.

Hacıömeroğlu, G. (2013). Sınıf öğretmeni adaylarının öğretim için matematiksel bilgisi: öğrencilerin toplama ve çıkarma işlemlerine ilişkin çözümlerinin analizi. Eğitim ve 
Bilim, 38(168), 332-346. $\quad$ Retrieved from http://eb.ted.org.tr/index.php/EB/article/view/1915

Henry, V. J., \& Brown, R. S. (2008). First grade basic facts: An investigation into teaching and learning of an accelerated, high-demand memorization standard. Journal for Research in Mathematics Education, 39(2), 153-183.

Iş1k, A., \& Mercan, E. (2015). Ortaokul matematik öğretmenlerinin model ve modelleme hakkındaki görüşlerinin incelenmesi. Kastamonu Eğitim Dergisi, 23(4), $1835-1850$.

İşleyen, T., \& Işık, A. (2003). Conceptual and procedural learning in mathematics. Journal of The Korea Society of Mathematical Education Series D: Research in Mathematical Education, 7(2), 91-99.

Kılcan, S. A. (2006). İlköğretim matematik öğretmenlerinin kesirlerle bölmeye ilişkin kavramsal bilgi düzeyleri. Yayınlanmamış Yüksek Lisans Tezi, Abant İzzet Baysal Üniversitesi Sosyal Bilimler Enstitüsü, Bolu.

Kinaach, B. M. (2002). A cognitive strategy for developing pedagogical content knowledge in the secondary mathematics methods course: Toward a model of effective practice. Teaching and Teacher Education, 18(1), 51-71.

Korkmaz, E., \& Gür, H. (2006). Öğretmen adaylarının problem kurma becerilerinin belirlenmesi. Balıkesir Üniversitesi Fen Bilimleri Enstitü Dergisi, 8(1), 64-74.

Markovits, Z., \& Sowder, J. (1994). Developing number sense: An intervention study in grade 7. Journal for Research in Mathematics Education, 25 (1), 4-29.

Miles, M. B., \& Huberman, A. M. (1994). Qualitative data analysis: an expanded sourcebook. (2nd Edition). Calif: SAGE Publications.

Millsaps, G. M., \& Underwood-Gregg, D. (2018). Elementary preservice teachers' learning to explain the invert and multiply algorithm. In Proceedings for the 45 th Annual Meeting of the Research Council on Mathematics Learning, 81-88. Retrieved from https://www.rcmlmath.org/assets/Proceedings/rcml\%20proceedings\%202018.pdf\#page $=88$

National Council of Teachers Of Mathematics. (2000). Principles and standards for school mathematics. Reston, Va: Author.

Saleh, S. F., Purwanto, P., Sudirman, S., \& Hidayanto, E. (2018). Pre-service elementary teachers' written communications: Explaining multiplication using area representations. International Journal of Insights for Mathematics Teaching (IJOIMT), $\quad 1(1), \quad 44-51 . \quad$ Retrieved from http://journal2.um.ac.id/index.php/ijoimt/article/view/3015

Ören Vural, D., \& Aylar Çankaya, E. (2020). Bilgi, inanç ve öğretim: Çarpma ve kesirlerde çıkarma işlemleri üzerine bir çalışma. Cumhuriyet Uluslararası Eğitim Dergisi, 9(1), 1-27. http://dx.doi.org/10.30703/cije.518799

Özdemir, İ. E. Y. (2008). Sınıf öğretmeni adaylarının matematik öğretiminde materyal kullanımına ilişkin bilişsel becerileri. Hacettepe Üniversitesi Ĕgitim Fakültesi Dergisi, 35(35), 362-373.

Thanheiser, E., Browning, C., Edson, A. J., Lo, J.-J., Whitacre, I., Olanoff, D., \& Morton, C. (2014). Prospective elementary mathematics teacher content 
knowledge: What do we know, what do we not know. And Where Do We Go?. The Mathematics Enthusiast, 11(2), 433-448.

Toluk-Uçar, Z. (2011). Öğretmen Adaylarının Pedagojik İçerik Bilgisi: Öğretimsel Açıklamalar. Turkish Journal of Computer and Mathematics Education, 2(2), 87102.

Tuna, A., Biber, A. Ç., \& Yurt, N. (2013). Matematik öğretmeni adaylarının matematiksel modelleme becerileri. Gazi Üniversitesi Gazi Ĕ̈itim Fakültesi Dergisi, 33(1), 129-146.

Urhan, S., \& Dost, Ş. (2016). Matematiksel modelleme etkinliklerinin derslerde kullanımı: Öğretmen görüşleri. Electronic Journal of Social Sciences, 15(59), 12791295.

Whitacre, I., \& Rumsey, C. (2018). Documenting the process of a prospective elementary teacher's flexibility development: Scaffolded strategy ranges and sociomathematical norms for mental computation, Cognition and Instruction, 36(4), 330-360. doi: 10.1080/07370008.2018.1491580

Van De Walle, J. A., Karp, K.S., \& Bay-Williams, J.M. (2013). Elementary and middle school mathematics: teaching developmentally (Eight Edition). New Jersey: Pearson Education Inc.

Yenilmez, K., \& Uygan, C. (2015). Sınıf öğretmeni adaylarının doğal sayılarda çarpma işleminin öğretimine yönelik sembol-problem-model bağlamında geliştirdikleri etkinliklerin incelenmesi. Ĕgitim ve Öğretim Araştırmaları Dergisi, 4(2), 283 292.

This is an Open Access article distributed under the terms of the Creative CommonsAttributionNonCommercial-ShareAlike 4.0 International (CC BY-NC-SA 4.0). For further information, you can refer to https://creativecommons.org/licenses/by-nc-sa/4.0/ 